\title{
Seven C's Communication Skills Problems in Writing Business Letter of English Major Undergraduate Students
}

\author{
Karnedi $^{1 *}$, M. Zaim ${ }^{2}$, and Mukhaiyar ${ }^{3}$ \\ ${ }^{123}$ Universitas Negeri Padang, Padang, West Sumatera \\ *Corresponding author. Email: karnedilpbamecpku@gmail.com
}

\begin{abstract}
This article examines the students' low ability and the degrees of their difficulties in writing business letters. The identified problems were based on the indicators of Seven C's communication skills. Students had low skills in writing opening, body, and closing paragraphs of business letters. Questionnaires and tests were the main instruments. There were 62 students from two classes from different Universities who followed the tests. The findings showed that a) completeness students had some lack of organization. A few of them provided the necessary information and answered the question asked. b) Conciseness, they had a little problem eliminating a wordy expression, c) Consideration, they had little or no attempt at connectivity, d). Concreteness, the students had a problem in emphasizing positive, pleasant facts. They sometimes had limited vocabulary, and frequent errors hinder the expression of ideas, e) Clarity, they had a few chose the imprecise, not-concrete, and familiar words. They had little or no attempt at connectivity, f). Courtesy, students had difficulties in using expressions that show respect. g). Correctness, they still kept having a big problem in using the right level of a language. Simply, they made errors of grammar or word order very frequently; the reader often has to rely on their interpretation. The results of students' responses frequencies questionnaire toward the difficulties in writing business letters based on the Seven C's communication skills indicators showed that most of them really agreed that the Seven C's were very difficult to implement in writing.
\end{abstract}

Keywords: Seven C's communication skills, writing a business letter

\section{INTRODUCTION}

Writing skills are the most difficult skills to acquire in a foreign language, and crucial in language development, and metacognitive skills [1]. The ability to compose business correspondence is a scarce marketable skill [2]. Moreover, for particular colleges, English correspondence or letter writing is one of the compulsory courses. To take this course, the students have to pass the other English courses. In other words, a student is not allowed to take a letter-writing or correspondence course since he or she fails in taking one of the requirements of the above courses. For the English students, this course is offered in the fifth semester because they have to pass some compulsory courses such as Vocabulary Building, Intermediate Vocabulary, Writing I, Writing II, Grammar I, II, III, and IV before taking the English Correspondence. Generally, the course covers three kinds of letters such as personal letters, social letters, and business letters. The personal letter covers a love letter and a letter for parents etc. The social letter covers apologies, condolence, invitations, thank you letter. The business letter covers acknowledgment letter, letter of requesting payment, collection letter, complaining letter, replying to complaints, orders, application letter, etc. The students focus on learning business letters. It is caused by three kinds of English letters, a business letter is one of the important and useful parts to study. The students are also expected to master the English business. The indicators of a good letter are completeness, conciseness, consideration, concreteness, clarity, courtesy, and correctness. These are called the Seven C's.

Some students found that writing is hard for them because they have a limited vocabulary. They also had low motivation in studying. It was caused by internal factors and external factors. The Internal factors include a lack of basic knowledge about the principles of writing letters, low vocabulary, and being unable to master grammar. The external factors can be categorized into language facility or the material and the teaching method and technique. It may be that the lecturers have not had special training in this area.

The researchers gave a pre-test to the students to find out the students' ability in writing the letter. The researcher asked the students to write a simple business 
letter in English by using their own words. The results were not so good. Most students did some mistakes. They did not compose effective writing namely seven C's. The researcher assumed that there were several writing problems faced by the students. Even though they are English students but composing a formal English letter is still hard for them. As a result, after getting a final exam only $30 \%$ of the students got an excellent grade. In other words, most of the students failed. After scoring the students' test results, the researcher found that the average scores of each component of seven C's business letter writing indicators as follow: Completeness (60\%), Conciseness $(56,7 \%)$, Consideration (53,7 \%), Concreteness $(53,3 \%)$, Clarity $(52,9 \%)$, Courtesy (52,9 $\%)$ and Correctness $(41,8)$. The Mean Score of the test was 53.2. It meant their rating quality was inadequate. They got poor scores.

The other facts, the researcher found that students got low or bad grades in letter writing. 5 from 35 students (14.3\%) got 70.10 students $(28.5 \%)$ got 50 and 20 students $(57.2 \%)$ got 30 . They can't compose an effective English letter. It takes time when they try to write an English letter. The sentences are messy. Simply, the students have no background knowledge about the indicators and components of a good letter.This study intends to answer the following research questions:

a) What are the results of students' tests in writing an English business letter?

b) How are the students' difficulties degrees in writing English business letter based on the Seven C's indicators.

\section{LITERATURE REVIEW}

\subsection{Issues in the Implementation of Writing Business Letter}

The prior to the 1860 's business letter writing usually originated business letter by dictation to a secretary writing shorthand Besides, more broadly, the importance of letters in that phenomenon [3]. Tertiarylevel learners' business letter writing is reflected in the use of modal sequences [4]. Six principles designed to prevent writing difficulties as well as to orbuild writing skills. [5] Moreover, According to [6] it has different classifications of writing. Writers changing major goals or even establishing entirely new ones based on what has been learned in the act of writing. Regarding research findings, the followings are the results of the research related to writing and business letters that have been conducted in various fields and different countries. According to [7] the role writing plays in content area learning. The highest writing scores were found for first name writing compared to writing or copying letters and numbers [8] Teaching writing encourages composition beyond elementary-level sentence exercise [9]. The results of the study revealed effects of different writing tasks on children's writing speed and writing accuracy. [10]. In the result of their research found that full block format was used on $48 \%$ of the letters followed by the semi-block with $39 \%$ [11] No significant difference between the performance of male and female students and the students of public and private schools [12]. The Cooperative language learning. (CLL) could develop their writing skills [13]. ESL learners had similar difficulties in academic writing.[14]. The learning process determines the students' achievements. [15]

\subsection{Seven c's Communication Skills}

Before discussing the principle of communication, the definition of business letters should be clearly defined. Understanding how to design your communication to give you the best chance of success, whatever the variety of business English used by your target audience [16]. The indicators of a good letter should be in seven C. They are completeness, conciseness, concreteness, consideration, clarity, courtesy, and correctness. The followings are the brief conclusions of Seven C's as the characteristics of good business letter writing; 1) Completeness contains all facts the readers or listener needs. A complete letter covers: providing all necessary information, all questions asked and giving something extra. 2) Conciseness. A concise message is complete without being wordy. 3) Consideration tries to put yourself in their place.4) Concreteness. Communicating correctly means being specific, definite, and vivid rather than vague and general. 5) Clarity. Giivng the meaning of the readeraccurately. 6) Courtesy involves being aware of the perspective of others, and their feelings. 7) Correctness uses proper grammar, punctuation, and spelling.[17]

Based on the above quotations, it can be concluded that a good writer should be able to minimize mistakes in writing. By mastering the seven characteristics, the students are expected to write concrete, concise, considerate, polite, clear, and correct business letter writing. Writing is conveying information or expression of original ideas consecutively in the new language. Writing is a thinking process, it is an artistic composition and the development of sharing and designing ideas through a text. Writing plays an important role in language learning. Writing is one of the best ways to learn. Writing is one of the most difficult subjects for students to master. Many factors should be taken into a consideration such as grammar, vocabulary, the rules of writing, etc. There are many kinds of writings. One of the formal writing subjects is letter writing or correspondence. Many researchers have already conducted studies related to English writing. 
Yet, in this case, there have not been found any research problems regarding business letter writing that used Seven C's Communication Skills as the indicators in assessing students' writing in business letters. Simply, these experts' statement shows that the importance of understanding and mastering of letter writing is not only for students but also for social practices.

\section{METHOD}

This article uses quantitative and qualitative methods. Collecting numerical data and explaining phenomena define as quantitative research. It is analyzed mathematically based methods [18]. Qualitative research attempts to explore a host of factors that may be influencing a situation [19] Simply, quantitative and qualitative research are traced with an emphasis on identifying diverse methodologies [20].

There were two kinds of data namely quantitative data and qualitative data. The qualitative is data about factors that influence the development of writing a letter. The factors that influence quantitative data such as media, materials, methods used in teaching, activities, teachers' approach, and classroom management. The quantitative data was data about the development of students' letter writing ability in the form of mean scores and percentages.

\subsection{Participants}

The participants of the study were students at two private universities taking an English business letter writing course. The samples of these institutions were S1 degree of English students. There were 62 English students took part in this test. Class $5 / 2$ with 32 students were from English Teaching Training Education and Class B with 30 students from the English Literature program. The chosen places were Universitas Lancang Kuning (Unilak) and Sekolah Tinggi Ilmu Bahasa Asing (STIBA) Persada Bunda Pekanbaru, Riau, Indonesia. The reasons for choosing these institutions because they are private educational institutions, so their status level was the same.

\subsection{Instruments}

Two kinds of instruments that used in this research such as questionnaires and tests. The questionnaires were given to find out the students' difficulties in writing a business letter based on the lecturers' responses. Tests were given to find out the students' ability in writing business letters. The tests were conducted before the researchers did any treatment or implemented any teaching strategy. The instruments used to collect quantitative data by giving tests to Class A and B. Before the test was implemented, the validity of the business letter writing test instrument was validated by 3 validators such as assessment experts, language experts, and material/design expert. The questionnaire for a test of students' difficulties in writing paragraphs of the business letter had 4 indicators such as always, sometimes, seldom, and rarely and it also had 27 subindicators. This questionnaire had been given to 3 English business letter writing at two private universities.

\subsection{Procedure}

Data were collected from 62 students of 2 private universities. The data were taken in November 2019. The test and questionnaire were the instruments of this research. The data were taken from English students of the fourth semester. The quantitative data were the data about the students' letter writing ability in the form of mean scores and percentages. To score students' letter writing mastery, this research used scoring rubric (Adopted from Analysis of the Tests and Rating Quality for Business Letter Writing Based on Seven C's [21] and Analytic Scoring [22] and calculated through the following formula:

$$
\begin{aligned}
& \mathrm{X}=\sum \mathrm{xi} \\
& \mathrm{n} \\
& \text { where: } \mathrm{X} \text { : Mean } \\
& \sum x i \text { Sum of students' score } \\
& \text { n: Sum of students' amount }
\end{aligned}
$$

\begin{tabular}{|c|c|c|c|c|c|c|c|c|c|c|}
\hline \multirow[b]{2}{*}{ No } & \multirow[b]{2}{*}{ Rating Quality } & \multicolumn{8}{|c|}{ Scores and Indicators } & \multirow[b]{2}{*}{$\begin{array}{l}\text { Total } \\
\text { Score } \\
\end{array}$} \\
\hline & & 1 & 2 & 3 & 4 & 5 & 6 & 7 & $\begin{array}{l}\text { Score in } \\
\text { Letter }\end{array}$ & \\
\hline 1. & $\begin{array}{c}\text { 20-18: } \\
\text { Excellent to Good } \\
17-15:\end{array}$ & 5 & 5 & 5 & 5 & 5 & 5 & 5 & A & $100-87$ \\
\hline 3. & $\begin{array}{c}\text { Good to Adequate } \\
\text { 14-12: }\end{array}$ & 4 & 4 & 4 & 4 & 4 & 4 & 4 & B & $86-79$ \\
\hline 4. & $\begin{array}{l}\text { Adequate to Affair } \\
\qquad 11-6\end{array}$ & 3 & 3 & 3 & 3 & 3 & 3 & 3 & $\mathrm{C}$ & $78-68$ \\
\hline 5. & $\begin{array}{c}\text { Unacceptable-not } \\
5-1\end{array}$ & 2 & 2 & 2 & 2 & 2 & 2 & 2 & $\mathrm{D}$ & $67-56$ \\
\hline & College-level work & 1 & 1 & 1 & 1 & 1 & 1 & 1 & E & $55-40$ \\
\hline
\end{tabular}

Table 1 Analysis of the Tests and Rating Quality for Business Letter Writing

Notes: Excellent means: like an educated native writer. Indicators of Letter Writing:

1. Completeness. 2. Conciseness.3. Consideration.

4. Concreteness.5. Clarity.6. Courtesy. 7. Correctness.

The following table used to calculate the students' degrees toward the difficulties in writing a business letter based on Seven C's indicators: 
Table 2 Students' Degrees toward the Difficulties in Writing English Business Letter

\begin{tabular}{|l|c|c|}
\hline No. & Rank Scores & Category \\
\hline 1. & $1=1$ to 1.6 & Low \\
\hline 2. & $2=1.7$ to 2.3 & Middle \\
\hline 3. & $3=2.4$ to 3.5 & High \\
\hline 4. & $4=3.6$ to 4 & Very High \\
\hline
\end{tabular}

Adapted from [23]

\section{RESULTS AND DISCUSSION}

As stated in the previous research questions, this research aimed at finding out the result of business letter writing tests and students' difficulties degrees in writing business letters based on the indicators of Seven C's Communication Skills.

4.1. The students' business letter writing test results. Table 3 the Results of Letter Writing Test Based on Seven C's Indicators in Percentages

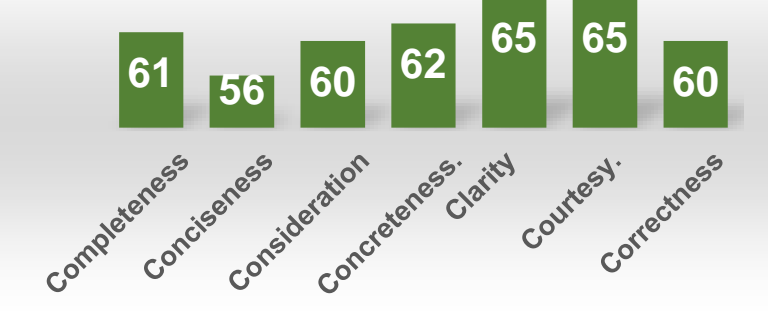

Based on the table and the diagram above can be described as the following: a). The students' letter writing ability in using completeness was $61 \%$ (Good). It means that the students had some lack of organization; rereading required for clarification of ideas. A few of them provided the necessary information and answered the question asked, b). The students' letter writing ability in using conciseness was $56 \%$ (Fair). It means they had a little problem eliminating a wordy expression, still included the irrelevant material, or they had limited vocabulary, c). The students' letter writing ability in using consideration was $60 \%$ (Fair). It means they had little or no attempt at connectivity, though the reader can deduce some organization, d). The students' letter writing ability in using concreteness was $62 \%$ (Fair). It means that the students had a problem in emphasizing positive, pleasant facts. They sometimes had low vocabularies and a lack of ideas, e). The students' letter writing ability in using clarity was $65 \%$ (Fair). It means that the students a few chose imprecise, not-concrete, and familiar words. They had little or no attempt at connectivity, though the reader can deduce some organization,f). The students' letter writing ability in using courtesy was $65 \%$ (Fair). It means that the students had difficulties in using expressions that show respect. Their communication is misused structure or vocabulary items, and g). The students' letter writing ability in using correctness was $60 \%$ (in-adequate). It shows that the students still kept having a big problem in using the right level of language, checking the accuracy of figures, facts, and words, and maintaining acceptable writing mechanics. Simply, they made errors in grammar, word choice, and punctuations. 4.2. The Questionnaire Results of Students' Responses

Table 4. Questionnaire Results of Students' Responses Frequencies toward the Difficulties in Writing English Business Letter Based on Seven C's Indicators

\begin{tabular}{|c|c|c|c|c|c|c|c|c|}
\hline \multirow[t]{3}{*}{ No } & \multirow{3}{*}{$\begin{array}{l}\text { Letter Writing } \\
\text { Indicators }\end{array}$} & \multicolumn{4}{|c|}{ Students' Answer } & \multirow[t]{3}{*}{ Total } & \multirow[t]{3}{*}{ Average } & \multirow[t]{3}{*}{ Category } \\
\hline & & Always & Sometimes & Seldom & Rarely & & & \\
\hline & & 4 & 3 & 2 & 1 & & & \\
\hline 1 & Completeness & 49 & 8 & 3 & 2 & 228 & 3,7 & Very High \\
\hline 2 & Conciseness & 48 & 7 & 4 & 3 & 224 & 3.6 & Very High \\
\hline 3 & Consideration & 52 & 5 & 3 & 2 & 231 & 3,7 & Very High \\
\hline 4 & Concreteness & 55 & 4 & 2 & 1 & 237 & 3.8 & Very High \\
\hline 5 & Clarity & 56 & 3 & 1 & 2 & 239 & 3,8 & Very High \\
\hline 6 & Courtesy & 41 & 7 & 8 & 6 & 207 & 3,3 & High \\
\hline 7 & Correctness & 54 & 4 & 2 & 2 & 234 & 3,8 & Very High \\
\hline
\end{tabular}

The table above showed that 1 ). The average score for completeness is 3,7. It is in a very high category. It meant that students always find difficulties in writing the completeness of the letters. It is hard for them to contain all the facts the readers or listener needs for the reaction, complete letter covers, and giving the information needed 2 ). The arrange score for conciseness is 3,6 . It is in a very high category. It meant that students always find difficulties in writing the conciseness of the letters. It is hard for them to complete a message. 3 ). The arrange score for consideration is 3,7 . It is in a very high category. It meant that students always find difficulties in writing consideration. 4) The arrange score for concreteness is 3,8 . It is in a very high category. It meant that students always find difficulties in writing the concreteness of the letters, 5) The arrange score for clarity is 3,8 . It is in a very high category. It meant that students always find difficulties in writing the clarity of the letters. It was hard too; (a). Select the right and familiar words. (b). Build sentences and paragraphs effectively, 6) The arrange score for completeness is 3,3. It is in a high category. It meant that students sometimes find difficulties in writing the completeness of the letters. Courtesy. They always find difficulties to show appreciative and respectful expressions, and 7). The arrange score for correctness is 38. It is in a very high category. It meant that students always find difficulties in writing the correctness of the letters Correctness. They always find difficulties in using grammar, punctuation, and spelling. 


\section{CONCLUSION}

In conclusion, the results of the students' test indicated that they found difficulties in writing seven C's communication skills. Most of the students answered that they always find difficulties in composing the completeness, conciseness, consideration, concreteness, clarity, courtesy, and correctness of business letters. Finally, to achieve the best teaching goal, it is needed to apply a teaching model that can stimulate the students' motivation to enhance their business letter writing.

\section{REFERENCES}

[1] B. F. Klimova, "The importance of writing," Indian J. Res., vol. 2, no. 1, p. 211, 2013, doi: DOI: $10.15373 / 22501991 / J A N 2013 / 4$.

[2] A. B. Geffner, Business letters the easy way. Barron's Educational Series, 1998.

[3] S. D. Lewis, "The effect of word processing on business letter writing," Delta Pi Epsil. J., vol. 21, no. 2, p. 26, 1979.

[4] Q. Xu, R. J. Jiao, X. Yang, M. Helander, H. M. Khalid, and A. Opperud, "An analytical Kano model for customer need analysis," Des. Stud., vol. 30, no. 1, pp. 87-110, 2009.

[5] L. P. Rivard and S. B. Straw, "The effect of talk and writing on learning science: An exploratory study," Sci. Educ., vol. 84, no. 5, pp. 566-593, 2000.

[6] S. Graham, K. R. Harris, and L. Larsen, "Prevention and intervention of writing difficulties for students with learning disabilities," Learn. Disabil. Res. Pract., vol. 16, no. 2, pp. 7484, 2001.

[7] J. A. Langer and A. N. Applebee, How writing shapes thinking: A study of teaching and learning. NCTE research report No. 22. ERIC, 1987.

[8] V. J. Molfese, J. Beswick, A. Molnar, and J. Jacobi-Vessels, "Alphabetic skills in preschool: A preliminary study of letter naming and letter writing," Dev. Neuropsychol., vol. 29, no. 1, pp. 5-19, 2006.

[9] A. Raimes, Techniques in teaching writing. ERIC, 1983.

[10] N. Sõvik and O. Arntzen, "A developmental study of the relation between movement patterns in letter combinations (words) and writing.," 1991.

[11] S. R. Lines and R. B. Carodine, "A study of business letter features," J. Forensic Sci., vol. 50, no. 4, pp. JFS2004459-4, 2005.

[12] J. M. Javed, Nazli Wu Xiao, and S. Nazli, "A study of students' assessment in writing skills of the English language," Online Submiss., vol. 6, no. 2, pp. 129-144, 2013.
[13] M. M. A. Mahmoud, "The effectiveness of using the cooperative language learning approach to enhance EFL writing skills among Saudi university students," J. Lang. Teach. Res., vol. 5, no. 3 , p. $616,2014$.

[14] I. A. H. Al Badi, "Academic writing difficulties of ESL learners," in The 2015 WEI international academic conference proceedings, 2015, vol. 1, no. 1 , pp. 65-78.

[15] K. Karnedi, "A Study on learning styles: visual, auditory and kinesthetic at English literature students of STIBA persada bunda Pekanbaru," J. residu, vol. 1, no. 1, pp. 48-60, 2017.

[16] F. Talbot, How to Write Effective Business English: The Essential Toolkit for Composing Powerful Letters, Emails and More, for Today's Business Needs. Kogan Page Publishers, 2009.

[17] H. Henderson, Practical business communication. Golden Books Centre.SDN.BHD Kuala Lumpur.International Communications., 2005.

[18] D. Muijs, Doing quantitative research in education with SPSS. Sage, 2010.

[19] D. R. Hancock and B. Algozzine, Doing case study research: A practical guide for beginning researchers. Teachers College Press, 2017.

[20] A. Marshall, L. Jackson, D. Drummond, and S. Camara, "The human voice of social-ecological restructuring II: Youth, restructuring, education and health," RE Ommer Coasts Under Stress Res. Proj. Team (Eds.), Coasts under Stress Restruct. Soc. Ecol. Heal., p. 241, 2007.

[21] H. Henderson, Practical business communication. golden books centre.SDN.BHD Kuala Lumpur. international communications. 2005.

[22] J. D. Brown and K. M. Bailey, "A categorical instrument for scoring second language writing skills," Lang. Learn., vol. 34, no. 4, pp. 21-38, 1984.

[23] S. Sugiyono, "Metode penelitian kuantitatif dan kualitatif dan R\&D." ALFABETA Bandung, 2010. 